\title{
Installing a More Coercive Senate for Enhanced Fiscal Capacity within the Counties of Kenya
}

\author{
Melissa Mungai *
}

\begin{abstract}
The clamour to divest the Kenyan parliament of its senate has been championed by a handful of critics who describe this parliamentary house as weak and a burden to taxpayer money. The root of such conclusions could be that the senate has legislative power that is less clear than that of the national assembly. With clearer and enhanced authority, the senate will be able to carry out its function of representing county interests at the national level effectively, more so with regard to the vertical and horizontal allocation of revenue. This paper seeks to make an argument in favour of the senate by illustrating its significant role as the custodian of devolution in Kenya and more specifically in the building of county fiscal capacity.
\end{abstract}

\section{Introduction}

Upper houses have been criticised for having both too much power and too little, for being too democratic or not democratic enough, or for being a carbon copy of the lower house. ${ }^{1}$ Take into account the subsequent reactions reported over time. The Senate of the Republic of Kenya is the 'lower' house, and is weak. ${ }^{2}$ The context of this criticism was a follow-up after the senate expressed its aggravation at the loss of one billion shillings, which was allocated to them for oversight and implementation of devolution. ${ }^{3}$ Thus the continuation of the

* The author is an LL.B student at Strathmore University Law School in Nairobi, Kenya.

1 Focus on the Senate: Modern concepts in the functioning of senates in bicameral parliamentary systems, Memorandum in preparation for the 16th meeting of the Association of European Senates, The Hague, Netherlands on 21-22 May 2015.

2 Goin J, 'Duale tells Senate on referendum: Bring it on' Capital News, 17 June 2015 http:/ /www. capitalfm.co.ke/news/2015/06/duale-tells-senate-on-referendum-bring-it-on/ on 16 June 2016.

3 Kiplang'at J, 'Senators to receive Sh1bn for oversight' Daily Nation, 11 March 2015- < http:/ /www. nation.co.ke/news/politics/Senators-Funds-Allocation-Oversight/-/1064/2650174/-/rg0sx2z/-/ 
critique was that such monies would have been wasted, as it would be 'pocket money' for the senators who already draw a salary 'for nothing'. Another misappraisal is that its apparent powerlessness has caused it to be branded the house of retirees' ${ }^{5}$ (even though some of the senators are youthful). ${ }^{6}$ To boot, it has been purported that Kenyans are over-represented with people who spend more time stealing from the taxpayer instead of delivering services and therefore if we have to have thieves, let's have fewer thieves. ${ }^{7}$

While all the above vilification may be founded on a poorly investigated piece of research it is of worth to question why the senate was installed in the first place. Among the constitutional changes following the promulgation of the Constitution of Kenya was the re-establishing of the senate. ${ }^{8}$ This was a move towards bi-cameralism whose rationale under constitutional theory is to ensure a horizontal check and balance on legislative power and to prevent a dictatorship of the majority. ${ }^{9}$ Its drawbacks have led to the statements above in disfavour of the upper house. In fact, the Kenya Human Rights Commission reports that:

'The constitutional allocation of legislative power in Kenya has been faulted for not laying enough emphasis on this important role of diffusing the tyranny of the majority through the 'one interest, one vote principle' and consequently, this has resulted in unending public debate on the legislative authority of senate'. ${ }^{10}$

index.htm> on 18 June 2016.

$4 \quad-\quad<$ http://www.capitalfm.co.ke/news/2015/06/duale-tells-senate-on-referendum-bring-it-on/> on 16 June 2016.

5 Being of old age was upheld by John Jay when he wrote "By excluding men under thirty five from the first office and under thirty from the second, it confines the electors to men of whom the people have had time to form a judgment, and with respect to whom they will not be liable to be deceived by those brilliant appearances of genius and patriotism, which, like transient meteors, sometimes mislead as well as dazzle." Hamilton A, Jay J, Madison J, The federalist, The Modern Library, New York, 1941, 417.

6 Katana J, 'Do we really need the senate' The Star, 13 February $2016-<$ http://www.the-star.co.ke/ news /2016/02/13/do-we-really-need-the-senate_c1293456?page=0percent2C1> on 16 June 2016. The criticism was given in one of the series of rallies for the Punguza Mrigo (Kiswahili for reduce the luggage although in this case it is more derogatory hence reduce the burden seems more appropriate) campaign which aims to lure Kenyans into scrapping the offices of the senate and women representatives as well as decrease the number of counties through a constitutional amendment. See Thairu N, 'Kiambu Woman Rep criticises PunguzaMzigo' The Star, 12 May 2016 - < http://www. the-star.co.ke/news/2016/05/12/kiambu-woman-rep-criticises-punguza-mzigo_c1348595>on 11 August 2016.

8 Kirui K and Murkomen K, The legislature: Bicameralism under the new constitution, Society for International Development, Nairobi, 2011, 15. The authors write that the senate is unique owing to the specificity of its functions.

9 Kenya Human Rights Commission, Functions and responsibilities of elected state members, 2014, 26 http:// www.khrc.or.ke/mobile-publications/economic-rights-and-social-protection-er-sp/49-khrc-booklet-state-officers/file.html on 16 June 2016.

10 Kenya Human Rights Commission, Functions and responsibilities of elected state members, 2014, 28. 
Ghai writes that the senate tends to be a lonely body often clashing with governors and the national assembly because it feels ignored. ${ }^{11}$ Agreeing with the assertion that the Constitution of Kenya, if properly implemented, carries great promise for the people of Kenya, and that it offers the country a chance for all citizens to transform society, ${ }^{12}$ this paper seeks to prove the importance of the senate towards the counties' economic growth through proposing the conferral of more powers. The first part gives a summary of the tempestuous history of the senate, which was characterised by a series of deprivations of legislative authority. The crux of the paper is an analytical discussion on how the senate performs its function of charting and steering the way for the allocation of revenue to the 47 counties to better their fiscal capacity. Lastly, this article concludes with instances of improvement borrowing from the relatively effective federal systems in the United States of America (USA).

\section{i. Definition of key concepts}

Joseph Nye in his article 'Soft Power' writes that when it comes to power one must ask the question power for what ${ }^{13}$ It is of significance especially when it comes to a fairly new decentralised government. As the World Bank reports:

'Decentralisation comes in many shapes and sizes, but in every instance, it involves changing the institutional rules that divide resources and responsibilities among levels of government. Politicians and bureaucrats thus fight over decentralisation for the same reason that they fight over the design of state institutions more generally: their power and authority are at stake. ${ }^{14}$

Coercive power, synonymous with hard command power (or hard power), can be described as authority that is dependent on fear, suppression of free will and threats for its existence. ${ }^{15}$ Moving away from this meaning, the paper adopts the definition given by a working paper on bi-cameralism, which states that coercive power is said to exist where the second chamber has the formal capacity to veto legislation originating from the first chamber. ${ }^{16}$ The author adds that other

11 Ghai Y, 'South African and Kenya systems of devolution: A comparison' in Steyler N and Ghai Y (eds), Kenya-South African dialogue on devolution, Juta and Company Property Ltd, Claremont, 2015, 22.

12 Para.8, International Legal Consultancy Group v Senate and another [2014] eKLR.

13 Nye J, 'Soft power' Foreign Policy, 80 (1999), 160.

14 The World Bank, Devolution without disruption: Pathways to a successful new Kenya, 2012, 7.

$15-<$ http://www.businessdictionary.com/definition/coercive-power.html> on 8 August 2016.

16 Kirui K and Murkomen K, The legislature: Bicameralism under the new constitution, 16. The authors continue by stating that such power is to be exercised either in the senate's proactive or reactive functions. In terms of its law-making function the senate originates bills concerning counties in parliament and in so doing it will be proactive. When it scrutinises the bill in the second instance, that is, it did not 
semblances of hard power could stem from clearly defined functions in the constitution, which could entail a longer duration in office than the first chamber and exclusive jurisdiction over duties such as treaty-making power in the USA. This can be contrasted with soft power whereby the senate acts as a corrective mechanism within the national assembly with no authority to pass acts, as is the case in Sweden. ${ }^{17}$ However, it must be noted that soft, otherwise known as cooptive, power is just as important as hard command power because it encounters less resistance due its persuasive nature. ${ }^{18}$

Fiscal capacity according to Martinez-Vazquez and Boex refers to the potential ability of governments in the region to raise revenue from their own sources in order to pay for a standardised basket of public goods and services. ${ }^{19}$ It is one of the essential ingredients of a formula for a transfer of revenue system whose possible aim is to provide each local government with sufficient funds to deliver a centrally pre-determined level of services. ${ }^{20}$

To sum up these concepts in relation with the subject matter, the paper sets its sights on proving that the senate with secured coercive authority would enable the counties through their respective governments to take charge of their own economic affairs. This is through clarity of functions, exclusive legislative powers and extended duration of official tenure. The gist of the article is that the senate is critical, it is the lifeblood of devolution; without it all is amiss economically for the counties.

originate it, the senate will be performing an appellate function and thus reactive.

17 Association of European Senates, Focus on the senate: Modern concepts in the functioning of senates in bicameral parliamentary systems, 2015, 4.

18 Soft power presents its ideologies as attractive thus citizens are more willing to obey because it is deemed as legitimate in their eyes. See more Nye J, 'Soft power', 167.

19 Martinez-Vazquez J and Boex L, 'Fiscal capacity: An overview of concepts and measurement issues and their applicability in the Russian Federation' International Studies Program, Working Paper Number 97-3, 1997, 2. - <http://icepp.gsu.edu/files/2015/03/ispwp9703.pdf> on 14 December 2016.

In the author's view this definition alludes to one of the objectives of devolution that communities should be able to manage their own affairs as prescribed in Article 174 (d), Constitution of Kenya (2010). It is also aligned with the aim of fiscal decentralisation which entails changing the locus of revenue generation by delegating the task to sub-national agencies, primarily, for the sake of expenditure autonomy whether or not the product enters the central kitty or is retained at the collecting agency for local spending; See Nyanjom O, 'Devolution inKenya's new constitution', The Society for International Development, Constitutional Working Paper Number 4, 2011, 3. In a similar vein, another end is fiscal autonomy which Mutakha Kangu writes is in two respects: access to sufficient revenue raised nationally and the ability for county governments to determine their own budgets and budgetary priorities. Read Kangu M, Constitutional law of Kenya on devolution, Strathmore University Press, Nairobi, 2015, 237.

20 Bird Rand Smart M, 'Intergovernmental fiscal transfers: International lessons for developing countries’ 30 World Development, 6 (2002), 904. 


\section{A Brief History of the Senate as the Custodian of Devolution}

Nwabueze writes that the control of the centre by one group, even if appropriate devices cannot check it, tends to excite less odium than if all powers are concentrated at the centre. ${ }^{21}$ The battle for the establishment of a senate in Kenya began before Independence was attained. The leaders at the time, especially from the Kenya African Democratic Union (KADU) advocated its installation. Ronald Ngala, the leader of KADU, believed that a two-chamber parliament with a senate especially charged with preserving the rights of the regions was the only way to ensure the continuing liberty of the individual. ${ }^{22} \mathrm{KADU}$ had wanted a strong senate, co-equal with the national assembly, to protect regional interests. What it got instead was a kind of House of Lords clearly inferior to the assembly and with no veto powers of legislation, but merely the power to delay a bill for a short period; nor was the senate as closely tied to the regions as KADU wanted. ${ }^{23}$ Eventually, by a constitutional amendment in 1966, the senate was abolished. ${ }^{24}$ According to political scientist Amukowa Anangwe, this was because of the political atmosphere at that moment as leaders were consolidating their power in order to enforce a centralised government. ${ }^{25}$ The abolition could be described as a merger because the senate and the national assembly were amalgamated and the life of the unicameral government extended by two years so as to delay dissolution of the first parliament. ${ }^{26}$ The centralised regime led the country to political instability so reform was needed. ${ }^{27}$ Reginald Maudling averred that the purpose of a second chamber apart from representing regional interests was to act as $a$ revising and reforming house. ${ }^{28}$

21 Nwabueze B, Constitutionalism in the emergent states, Hurst and Company, London, 1973 in association with Nwamife Publishers, Enugu, 1977, 97.

22 Proctor J, The role of the senate in the Kenyan political system, Institute of Developmental Studies, University College, Nairobi, 1965, 390.

23 Ghai Y, 'Devolution in Kenya: Background and objectives' in Steyler N and Ghai Y(eds), Kenya-South African dialogue on devolution, 73.

24 This was Constitutional Amendment 40 of 1966, which established a unicameral legislature. See - <http://www.monitor.co.ke/2015/03/16/amendments-in-kenyas-first-constitution/>on 18 November 2016.

25 - <http://www.standardmedia.co.ke/article/2000074383/will-past-setbacks-return-to-haunt-senate $>$ on 2 August 2016.

26 Media Development Association and Konrad Adenauer Foundation, History of constitution making in Kenya, 2012, 14.

27 The instability is demonstrated by events such as the reinstitution of political detention without trial in 1966, the attempted coup-d'etat of 1982, heavy rigging in the general elections of 1988 due to the use of unconventional mlolongo system (queuing), constitutional transformation of Kenya into a one-party state. See more Nyanjom O, 'Devolution in Kenya's new constitution', 7-8.

28 Proctor $\mathrm{J}$, The role of the senate in Kenyan political system, 391. 


\section{i. The chronology of constitutional senatorial power from 1963-2010}

In the Independence Constitution ${ }^{29}$ a bill could originate in either house of parliament except a money bill, which could only be brought forward by the House of Representatives. ${ }^{30}$ This quashed the wishes of KADU who desired a senate of co-equal status with the lower house. ${ }^{31}$ The first senate's authority was limited as it could not proceed upon bills other than those sent from the House of Representatives which in the opinion of the person presiding made provisions which included: the imposition, repeal or alteration of taxation; ${ }^{32}$ the imposition, payment, issue or withdrawal of any charge upon the Consolidated Fund or any other fund of the government; ${ }^{33}$ and the composition or remission of any debt due to the government. ${ }^{34}$ In addition the senate could not proceed upon any amendment to any bill, which in the opinion of the person presiding envisioned any of the provisions listed, ${ }^{35}$ or proceed in any motion (including an amendment to the motion) whose effect would touch on the provisions listed above. ${ }^{36}$ These bills collectively were known as financial bills and, as reflected in the stipulations, the senate could neither initiate nor veto them. ${ }^{37}$

The Wako Draft Constitution of 2001 did not envision any establishment of a senate, which led to its rejection by Kenyans in the 2005 referendum. ${ }^{38}$ One of the reasons for the rejection was that the draft did not resolve the limitations of a centralised government such as an all-powerful presidency. ${ }^{39}$ In the Revised Harmonised Draft Constitution of Kenya, developed in the post-2008 phase of constitutional review, the senate was charged with inter alia $a^{40}$ ensuring equity

\footnotetext{
Constitution of Kenya (Independence Constitution), (1963).

Section 59 (2), Constitution of Kenya (1963).

- $\quad$ http://www.ustawi.info.ke/index.php/senate/senate-under-the-old-constitution?showall=1> on 2 August 2016.

32 Article 60 (1) (a) (i), Constitution of Kenya (1963).

Article 60 (1) (a) (ii) and (iii), Constitution of Kenya (1963).

Article 60 (1) (a) (iv), Constitution of Kenya (1963).

Article 60 (1) (b), Constitution of Kenya (1963).

Article 60 (1) (c), Constitution of Kenya (1963).

- $\quad$ http://www.ustawi.info.ke/index.php/senate/senate-under-the-old-constitution?showall=1> on 2 August 2016.

38 This was the 'Orange/Banana' campaign where the 'No' camp won by fifty-eight percent; its rival camp garnered a total of 42percent. See 'Kenyans reject new constitution' BBC News, 22 November 2005 - <http://news.bbc.co.uk/2/hi/africa/4455538.stm> on 2 August 2016.

39 The Wako Bill suggested a strong presidential system in which parliament would play second fiddle despite the introduction of a nominal position as prime minister and, secondly, the impeachment procedure required a seventy-five percent parliamentary majority thus proving it difficult to depose a president. See moreAndreassen B andTostensen A, Of oranges and bananas: The 2005 Kenya referendum of the constitution, ChrMichelsen Institute (CMI) Working Papers, Norway, 2006, 7.

40 The other proposed functions of the senate included provision of an institution through which the
} 
in distribution of national resources and opportunities among all parts of communities in Kenya and acting as a house of review. ${ }^{41}$ The current constitution ${ }^{42}$ envisions four key roles of the senate, that is: representing the county interests, law making which is restricted to bills concerning counties, allocation of national revenue to the counties and powers of presidential impeachment. ${ }^{43}$ The last two represent their oversight powers. Of concern will be the allocation of national revenue as per Article 217, which suggests that once every five years the senate will determine the allocation of revenue for each county. ${ }^{44}$

\section{The Senate is Critical for the Counties' Economies}

As discussed in the history of the development of the senate, the chamber had limited powers with regard to shaping the economies of regional units in Kenya. The Independence Constitution had provisions that were essentially about ensuring that money was collected and expended by those who had the authority to do so, but there was lack of a real effort to ensure wisdom in financial decisions. ${ }^{45}$ The current constitution took the power of revenue sharing away from the executive and created new bodies, including the Commission on Revenue Allocation (CRA) and the senate, to lead a more transparent and objective process of deciding how to share resources. ${ }^{46}$ It should be noted that the power of the senate, in this regard, is not exclusive as it is shared with the national assembly save that the senate has special veto power; ${ }^{47}$ an issue that the author tackles later in the paper.

interests of the devolved governments are represented in the enactment of legislation concerning counties and to protect the interests of the county governments as well as an institution for special representation of women, persons with disabilities, minorities, and youth; approval of appointments and impeachment of the president or the deputy president. See Article 118 (a), (b), (e) and (f), Revised Harmonised Draft Constitution of Kenya (2010).

41 Article 118 (c) and (d), Revised Harmonised Constitution of Kenya (2010).

42 Constitution of Kenya (2010).

43 Article 96, Constitution of Kenya (2010).

44 Article 217(1), Constitution of Kenya (2010).

45 Constitution of Kenya Review Commission, The final report of the Constitution of Kenya Review Commission, 2005, 285.

46 Lakin J and Mudida R, Sharing resources fairly: The evolution of Kenya's revenue sharing formula 2012-2015, IBP Kenya and Strathmore Business School, Nairobi, 2015, 1.

47 This means that the national assembly can only reject a recommendation by the senate through a two-thirds vote. See more on supermajority. 
The senate may initiate a bill concerning counties such as the County Revenue Allocation Bill. ${ }^{48}$ This bill is determined upon once every five years and it constitutes the basis on which the counties receive a share of national revenue. ${ }^{49}$ The criteria for such allocation include: the need to ensure that county governments are able to perform the functions allocated to them, ${ }^{50}$ developmental needs of the counties, ${ }^{51}$ the fiscal capacity and efficiency of county governments, ${ }^{52}$ economic disparities within and among the counties as well as the need to remedy them, ${ }^{53}$ the need for economic optimisation of each county and, lastly, to provide incentives for each county to optimise its capacity to raise revenue. ${ }^{54}$

The senate is empowered to consult the CRA, county governors, the cabinet secretary responsible for finance as well as the public (which includes professional bodies) in order to determine how national revenue is to be shared among counties. ${ }^{55}$ A timeline of 60 days is given to the national assembly to deliberate upon the resolution of the senate after which it is required to vote to approve it with or without amendments or simply reject it. If the national assembly fails to meet the deadline, the resolution is considered approved without amendment and it shall thus be binding. ${ }^{56}$ In the event the resolution was amended or rejected, such standings must have been supported by a two-thirds vote. ${ }^{57}$ The idea of a two-thirds vote is also known as supermajority rule, which has its historical foundations on the premise that it is meant to subjugate the wisdom of the many to the wisdom of the few. ${ }^{58}$ At this stage, if the resolution is approved it is binding until a subsequent one is approved. ${ }^{59}$ Following an amendment or rejection, the senate may draft a new resolution, which means that the 60 -day deliberation

8 Article 110 (2) (ii), Constitution of Kenya (2010).

49 Article 217 (1), Constitution of Kenya (2010).

50 Article 203 (1) (d), Constitution of Kenya (2010).

51 Article 203 (1) (f), Constitution of Kenya (2010).

52 Article 203 (1) (e), Constitution of Kenya (2010).

53 Article 203 (1) (g), Constitution of Kenya (2010).

54 Article 203 (1) (i), Constitution of Kenya (2010).

55 Article 2172 (b), (c) and (d), Constitution of Kenya (2010).

56 Article 217 (5) (a), Constitution of Kenya (2010).

57 Article 217 (5) (b) (i) and (ii), Constitution of Kenya (2010).

58 'Merkley J, 'Why 'supermajority' no longer works in the Senate' Washington Post, 4 November 2011 - <https://www.washingtonpost.com/opinions/why-supermajority-no-longer-works-in-thesenate/2011/11/04/gIQAT8cdnM_story.html> on 2 August 2016. Merkley argues that this rule could be used destructively in the sense that it discredits and blocks the actions of the majority.

59 Article 217(7), Constitution of Kenya (2010). This section has been described as a Reversionary Position in the event that the Senate and the National Assembly do not agree on the criteria for division of revenue. See more: Mwenda A, Economic and administrative implications of the devolution framework. established by the Constitution of Kenya, Institute of Economic Affairs, Nairobi, 2010, 11. 
phase begins anew. ${ }^{60}$ Alternatively, a joint committee of both houses can mediate upon the conflicting interests of the national assembly and senate with regard to the resolution. ${ }^{61}$

\section{i. Implementation of the County Revenue Allocation Act (2016)}

This year, ${ }^{62}$ senators passed the County Allocation of Revenue Act ${ }^{63}$ paving the way for counties to access over 300 billion shillings in the next financial year; in its absence, no county government can get any funds from the national treasury. ${ }^{64}$ The formula (also known as second generation) that led to such a conclusion was a recommendation from CRA with the senate having the final say. ${ }^{65}$ The senate is charged with intergovernmental fiscal transfer together with the CRA both acting as counterbalancing forces against the national executive and the national assembly, respectively, in the sharing of national revenues. ${ }^{66}$

The constitution states that the sharing of revenue should be equitable. ${ }^{67}$ The equitable share is the main source of funding for counties: a single, unconditional block grant to carry out devolved functions. ${ }^{68}$ The Division of Revenue Bill reflects the same when it states that: 'The equitable share of revenue, thus determined by parliament, is an unconditional allocation to the county governments and therefore county governments are expected to plan, budget, spend, account and report on the funds allocated independently. ${ }^{69}$

60 Article 217 (6) (a), Constitution of Kenya (2010).

${ }^{61}$ Article 217 (6) (b), Constitution of Kenya (2010).

62 This paper was written in 2016.

63 County Revenue Allocation Act (Act No. 22 of 2016).

${ }^{64}$ Kiplang'at J, 'Kenya Counties set to get Sh300 billion after senate passes bill' Daily Nation, 7 June 2016

- <http://allafrica.com/stories/201606081044.html> on 16 June 2016.

65 - <http://www.crakenya.org/cra-consults-senate-on-second-generation-formula/>on 3 August 2016.

66 Task Force on Devolved Government, $A$ report on the implementation of devolved government of Kenya, 2011, 289. Counterbalancing here means that they act as oversight bodies.

67 See Article 202 (1), Constitution of Kenya (2010) which states that the sharing of national revenue between the national and county governments shall be equitable. This is also reflected in Article 201

(b), Constitution of Kenya (2010) that states that the public finance system shall promote an equitable society.

68 IBP Kenya, Kenya: Analysis of the Commission on Revenue Allocation's (CRA) 2016/17 recommendations on sharing revenue, 2016, 2. The fact that the equitable share of revenue is the main source of funding does not negate the fact that the counties still raise their own revenue through taxes on property, entertainment and any other taxes authorised by an Act of Parliament. See more Cheeseman N, Gabrielle L and Willis J, 'Decentralisation in Kenya: The governance of the governors' 54 The Journal of Modern African Studies, 2016, 15.

69 Appendix 5, Division of Revenue Act [2016]. 
In determining the allocation, two choices are considered the first of which is how much of the total national revenue has been collected for the distribution between the two levels of government (vertical share) followed by how much of the total national revenue should be distributed to each county (horizontal share). ${ }^{70}$ The three internationally recognised principles of revenue sharing are fiscal need, fiscal effort and fiscal capacity. ${ }^{71}$ The constitution of Kenya alludes to these principles in Article 203, which uses concepts such as developmental needs, fiscal capacity, incentives and optimisation to raise its own revenue. ${ }^{72}$ Of the three a country can create the formula that it intends to use whilst incorporating an emphasis on one of the three principles. Kenya's proposed formula asserts much weight on population as compared to other proxies such as equal share, fiscal responsibility, land area and poverty. ${ }^{73}$ Population was given the greatest weight because it is a simple and predictability-assuring measure. The counties with a lower population can therefore meet the equity threshold as they have a higher potential to pull their resources together through taxation if occupying a small area than a sparse population over a large area. ${ }^{74}$ The second-generation formula has added new proxies such as the personal emolument and development needs. ${ }^{75}$ The latter ensures that funds are allocated for education, health, water and infrastructure. ${ }^{76}$

The shortcoming of focusing on population is that some counties have fewer inhabitants but would benefit more development-wise. For instance the allocation for Nairobi County is 14 billion shillings, followed by Turkana's share of 11 billion shillings then a wide margin with the last county, Lamu, which will receive two billion for the 2016/2017 financial year. ${ }^{77}$ In contrast, when it comes to the parameter for fiscal capacity the county governments that are potentially

70 Lakin J and Mudida R, Sharing resources fairly: The evolution of Kenya's revenue sharing formula 2012-2015, IBP Kenya and Strathmore Business School, Nairobi, 2015, 6.

71 Lakin J and Mudida R, Sharing resources fairly, 9.

72 Lakin J and Mudida R, Sharing resources fairly, 9.

73 The parameters for the second generational formula are 45percent on population which has been maintained since the first formula.

74 - <http://www.crakenya.org/wp-content/uploads/2013/10/CRA-RECOMMENDATION-ONEQUITABLE-REVENUE-SHARING-November-2014.pdf> on 5 August 2016.

75 Personal emolument means the money that will be allocated for the payment of former staff transferred from local authorities as well as the new staff who will fill in the devolved government offices. This money is to help the county governments cater for their increased wage bill demand. See more - $\quad$ http://www.crakenya.org/the-second-recommendation-for-the-basis-of-equitable-sharing-ofrevenue-among-county-governments/> on 5 August 2016.

76 - <http://www.crakenya.org/the-second-recommendation-for-the-basis-of-equitable-sharing-ofrevenue-among-county-governments/> on 5 August 2016.

77 The actual figures are Nairobi-Ksh 14,023,506,892; Turkana-Ksh 11,307,010,771 and Lamu -Ksh 2,214,008,743. See First Schedule, County Allocation Act (Act No. 22 of 2016). 
able to autonomously raise a higher amount of revenue receive less from the allocation than those who generate less revenue. ${ }^{78}$ This is perhaps the reason why federal states such as Ethiopia resort to basing their formula on fiscal gaps. This entails trying to narrow the disparities between the expenditure obligation (fiscal needs) and the regional units' capacity to generate their own revenue in order to reduce vertical fiscal imbalances. ${ }^{79}$ In addition, their formula takes into account parameters such as distance from per capita income and level of development. ${ }^{80}$

As evidenced in the County Allocation of Revenue Act and the constitution, the senate has a crucial role with regard to which formula is implemented. ${ }^{81}$ The senate reduced the amount to be transferred to the counties from approximately 331.8 billion shillings to 280.3 billion shillings because generally, if the amount recommended was to be settled on, the national government would be left with a wide financial gap, which could only be filled through financial borrowing. ${ }^{82}$ The senators passed the second generation formula after six months of negotiations with the CRA due to the fact that they did not approve its recommendations thus the current formula intends to reward counties that earn higher revenue as well as increase the revenue to be horizontally allocated..$^{83}$

78 If fiscal effort were to be considered the transfer of funds would be less where the county has made a lower effort to raise revenue thus it plays out as a reward system for counties that strive to raise their own funds. Read IBP Kenya, Analysis of CRA Proposal for Second Generation Formula Released in November 2014, 2014 < http://www.internationalbudget.org/wp-content/uploads/ Final-Memo-to-Senate-on-CRA-Proposal-2014.pdf> 5 August 2016.

It is argued that the level of revenue raised should not be the sole measure of fiscal capacity because different tax rates may apply in different regions, the enforcement effort in collecting such taxes may vary and the compliance of the general public in the given region to garner such taxes may vary as well. These causes of variance do not affect the potential ability to collect revenue more than they affect the level of revenue collected. See Martinez-Vazquez J and Boex L, 'Fiscal capacity: An overview of concepts and measurement issues and their applicability in the Russian Federation', 3-4.

79 World Bank, Ethiopia Public Finance Review: Poverty reduction and economic management, 2010, 21 - <http:// documents.worldbank.org/curated/en/530241468255278847/pdf/549520ESW0P1010IC0disclos ed04050120.pdf > on 5 August 2016.

80 CRA, CRA recommendation on the criteria for sharing revenue among counties for financial years 2015/2016, 2016/2017 and 2017/2018, 2014, 10 - <http://www.crakenya.org/wp-content/uploads/2013/10/ CRA-RECOMMENDATION-ON-EQUITABLE-REVENUE-SHARING-November-2014. pdf $>$ on 5 August 2016.

81 Article 217 (2) (b), Constitution of Kenya (2010).

82 Para. 16 of Appendix, County Revenue Allocation Bill (2016). Some of the additional reasons included reports from the national treasury which used a different revenue growth factor; some of the costs for roads had already been captured in the net value and the share allocated for public participation should in principle be generated by the counties themselves. See Para. 12 and 13 of Appendix, County Allocation Bill (2016).

83 Kiplang'at J, 'Kenya Senate passes new revenue sharing formula' Daily Nation, 20 April 2016 - <http://allafrica.com/stories/201604220634.html> on 14 June 2016. 
In conclusion, the County Allocation of Revenue Act will aid the regional units in realising their fiscal capacity foreshadowed in the objectives of devolution. The aim of every system of transfer is achieving vertical fiscal balance, which ensures that the revenues and expenditures of each level of government are approximately equal; otherwise there will be a widened fiscal gap, which becomes part of the problem in achieving horizontal fiscal balance. ${ }^{84}$ In similar vein, what happens to the counties when vertical allocation of revenue is imperilled? As it stands, according to Mutua:

'The counties own local revenue collection remains low with some struggling to maintain revenue levels from the former local authorities... Counties need to shore up their fiscal capacity to generate their own revenue which is critical in helping forge a social contract and legitimacy between citizens and the county government'. ${ }^{35}$

\section{Implications of a 'Non-Senate' Legislature on the Economies of Counties: Division of Revenue Act 2016 and a Case Study of Advisory Opinion 2 of 2013}

This section seeks to inquire into the effect on the counties' economies were the senate to be scrapped using arguments developed from the determination of a supreme court decision, which attempted to settle the question on whether the Division of Revenue Bill (2013) was a bill concerning the counties thereby under the authority of the senate or a bill for determination by the sole authority of the national assembly.

Generally, the bill determines the amount of money that is shared between the two houses of parliament. ${ }^{86}$ This is known as vertical share as aforementioned. ${ }^{87}$ Before the allocation of money to the counties, as has been discussed in County Revenue Allocation Bill, this distribution must be determined first. The criteria that guide the particular sums of revenue to be shared reflect, generally, the principle of equity ${ }^{88}$ in addition to taking matters such as national interest, ${ }^{89}$

\footnotetext{
84 Bird R and Smart M, 'Intergovernmental fiscal transfers', 900.

85 Mutua J, 'Emerging issues in county public finance management' in Bosire C and Gikonyo W (eds) Animating devolution in Kenya: The role of the judiciary, International Development Law Organisation, Judicial Training Institute and Katiba Institute, 2015, 140.

86 Article 218(1), Constitution of Kenya (2010).

87 Lakin J and Mudida R, Sharing resources fairly, 6.

88 Article 202 (1), Constitution of Kenya (2010). The county governments may at times receive an additional allocation from the national government's share of the revenue, either conditionally or unconditionally as stipulated in Article 202(2).

89 Article 203(1) (a), Constitution of Kenya (2010).
} 
national obligations ${ }^{90}$ and the needs of the national government. ${ }^{91}$

The process of enactment of this bill is imprecise as Article 218(2) only stipulates that the bill if passed should include a memorandum that entails an explanation of the revenue allocation, an evaluation of the bill in relation to the equalisation criteria and a summary of any deviation from the recommendations of the CRA where applicable. ${ }^{92}$ As a consequence of such ambiguity the national assembly passed the Division of Revenue Bill of 2013 without sending it to the senate, prompting the senators to seek an advisory opinion from the highest court. ${ }^{93}$ The bone of contention with regard to the bill was twofold: that the determination of such a bill falls within the sole authority of the national assembly within the context of money bills and secondly, that the senate had no constitutional authority to determine the bill. ${ }^{94}$ Counsel for the national assembly argued that the constitution dictates that the house is charged with the determination of division of revenue between the two levels of government and therefore may proceed upon enactment of the division of revenue bill without appending the opinion of the senate. They based such claims on Article 95(4) (a) of the constitution, which empowers the national assembly to determine the allocation of national revenue between the levels of government. ${ }^{95}$ Furthermore, the national assembly argued that if the senate were to be consulted and at the same time they had their own function of allocating national revenue to each county, this would jeopardise the efficiency of their law-making power.

As concluded in the advisory opinion ${ }^{96}$ before the Supreme Court, the senate and the national assembly are to act in synchronisation to promote the spirit of devolution and lay bare sound inter-government relations for coherence and consistency in legislation. The majority dictum was:

'The Division of Revenue Bill, 2013, was an instrument essential to the due operations of county governments, as contemplated under the constitution, and so was a matter requiring the senate's legislative contribution. Consequently, the speaker of the national

\footnotetext{
Article 203(1) (b), Constitution of Kenya (2010).

Article 203 1(c), Constitution of Kenya (2010).

Article 218(2) (a), (b) and (c) respectively, Constitution of Kenya (2010).

- <http://allafrica.com/stories/201606150090.html> on 16 June 2016.

Advisory Opinion 2 of 2013.
}

95 Lady Justice Ndung'u supported this claim by adjudging in her dissenting opinion that the word determine confirms the sole command and authority of the national assembly to make a conclusive resolution on the Division of Revenue Bill thus when it is introduced in the national assembly the senate has no role to play; it may only make an input before such introduction. See para. 260 and 278 of the Advisory Opinion 2 of 2013.

96 Advisory opinion 2 of 2013 between the Speaker of the Senate, the Senate of the Republic of Kenya and the Honourable Attorney General, the Speaker of the National Assembly. 
assembly was under duty to comply with the terms of Articles 110(3), 112 and 113 of the constitution, and should have co-operated with the speaker of the senate, as necessary, to engage the mediation forum for resolution of the disagreement'. ${ }^{97}$

Despite the contention, the bill was passed with the total shareable revenue amounting to 1,380.2 billion shillings, of which 1,093.9 billion shillings was allocated to the national government and thereafter 280.3 billion shillings was distributed to the county governments. ${ }^{98}$ The tragedy lies not in the exclusion of one house in the process of making laws; the tragedy lies in the fact that the constitution does not clearly define the functions of both houses, which consequentially affects the county governments' fiscal capacity. Wanyande writes that if the bulk of funding is from the national assembly there is a danger of counties becoming over-dependent thus without adequate financial resources county governments cannot deliver services satisfactorily. ${ }^{99}$ Therein presents a total contradiction to the rationale of devolution especially the objective that counties should be able to govern their affairs economically in a laissez-faire approach.

In the advisory opinion, the concerns brought out with regard to the need for consultation of both houses revealed that the main issue was time consciousness. There are several steps to be taken into thought when the bills are deliberated upon. These are the recommendations of the CRA, the resolutions of the senate or the national assembly and in the event of a standoff, the mediation process. ${ }^{100}$ All these procedures require prompt performance at least two months before the end of every financial year. ${ }^{101}$ There is no stalling or pause button to these legislative processes. Firstly, because they are determined once every five years in order to determine the financial arrears of the counties conclusively. Therefore, it can be argued that, for efficiency and in light of time constraints,

97 Advisory Opinion 2 of 2013, Para. 148. In addition to this, the two houses were instructed to take advantage of mediation in case of future conflicts when passing the bill.

98 - <http://www.president.go.ke/2016/05/06/revenue-allocation-bill-signed-into-law/> on $2 \mathrm{Au}-$ gust 2016. An explanation for the equitable allocation worth (Ksh 280.3 billion) to the county governments provides that the revenue is to cover the health sector in areas such as free maternal health care, leasing of medical equipment, level five hospitals and a special purpose grant for access to emergency medical services. See Appendix 7, Division of Revenue Act [2016].

99 Wanyande P, 'The implementation of Kenya's system of devolved government' in Steyler N and Ghai Y (eds), Kenya-South African dialogue on devolution, Juta and Company Property Ltd, Claremont, 2015, 438.

100 Para. 223 of the Advisory Opinion 2 of 2013. Lady Justice Ndung'u argues that the enactment of the Division of Revenue Bill is not suited to have a probability of a deadlock, that is, when both houses unable to reach a resolution in order passing a bill because this would precipitate financial crisis that would paralyse the workings of the entire government and even cause its collapse. Read Para. 283 of Advisory Opinion 2 of 2013.

101 Article 218(1), Constitution of Kenya (2010). 
the national assembly should handle the task alone. In English jurisprudence, a decision of 1968 affirmed this position:

'That all in aids and supplies, and aids to His Majesty in Parliament, are the sole gift of the Commons; and all bills for granting any such aids and supplies ought to begin with the Commons; and that it is the undoubted and sole right of the Commons to direct, limit and appoint in such bills the end, purposes, considerations, limitations and qualifications of such grants, which ought not to be changed or altered by the House of Lords'. ${ }^{102}$

Limitations are addressed by taking elements of context into consideration as well as asking the question why certain institutions were put into place. Kangu writes that the oversight power of the senate is restricted to revenue raised nationally and allocated to the county governments. However, it has no direct mechanisms for enforcement. ${ }^{103}$ In light of the foregoing the senate cannot implement its oversight role because of the various encumbrances. A counter argument could be that the senate is not the only tool for ensuring the security of devolution remains intact or more specifically that the senate is the only assurance of accountability when the national revenue is allocated to the two houses of government or the 47 counties. Other tools for accountability include the county assemblies which are charged with legislating on any laws that are incidental to the exercise of effective performance of the functions of the county government ${ }^{104}$ and the CRA which has the prerogative to recommend the basis on which equitable sharing of revenue between the national and county governments as well as among the 47 county governments will be carried out. ${ }^{105}$ In fact, unlike the county assemblies, Mukaindo writes that the senate offers weak linkages or representation of the county governments whose interest it seeks to protect at least revenue-wise. ${ }^{106}$

The Repealed Constitution established a parliament made up of the president and the national assembly. ${ }^{107}$ Unicameralism set the country back generally thus the constitution drafters learned from the historical lens the road to a better future and therefore getting rid of the senate is equivalent to getting rid of

\footnotetext{
Para. 73 of the Advisory Opinion 2 of 2013.

Kangu M, Constitutional law of Kenya on devolution, 280.

Article 185(2), Constitution of Kenya (2010).

Article 216 (1), Constitution of Kenya (2010).

106 Mukaindo P, 'Kenya's Devolution Implementation: Emerging Issues in the Relationship between Senate and County Governments' Unpublished LLM Thesis, University of the Western Cape, November 2014, 58-59.

107 Article 30, Constitution of Kenya (1963).
} 
devolution. ${ }^{108}$ The senate is designed to act as a bulwark against the tyranny of numbers that democracies sometimes create; to guard against the invisibility of minority interests. ${ }^{109}$

\section{Enhancing Senatorial Power to Install a More Coercive Senate}

This section argues that the senate needs clearly defined legislative power for the sake of consistency in carrying out its constitutional function. It will also expound on coercive power as defined earlier in this paper, which connotes functions such as exclusive legislative authority, increased pro-activity in the legislative process and extension of duration of term. The arguments will take a comparative view borrowing from the relatively effective federal systems of the USA.

\section{i. Clarity of mandate for consistent service delivery to the sovereign}

American judge and judicial philosopher Billings Learned Hand averred that law should not be foreign to the ears of those who are to obey it. ${ }^{110}$ The mandate of the senate is ambiguous as concluded in the advisory opinion. This needs to be rectified so that there is consistency and efficiency in the laws enacted. Regardless, there are stipulations within that try to minimise the event of inconsistent and inefficient law making. Article 110 of the constitution dictates that before either house originates a bill, the speakers of two houses must deliberate whether or not the bill is one that concerns counties. Senior Counsel Nowrojee averred that this stipulation is: '...the very fulcrum of the constitution's scheme of devolution: it seeks to guarantee the participation of the senate in the origination, determination and enactment of laws that affect the operations of the counties, which are the basic units of devolved government'. ${ }^{111}$

The advisory opinion emphasised the process of inter-chamber negotiations or legislation to determine which bill fits within the ambit of county bills or national bills because in the event of a deadlock there would be a possibility of

108 Makueni Senator Mutula Kilonzo avers that the push is appealing but if you have to do away with senate the country should be ready to do away with the devolved system of governance. See Kiplang'at J, 'Senators oppose scraping of senate, say move will kill devolution' Daily Nation, 8 December 2015- <http://www.nation.co.ke/news/politics/Senators-allege-plot-to-kill-devolution/-/1064/2988514/-/pnv5v5/-/index.html> on 16 June 2016.

109 Kenya Human Rights Commission, Functions and responsibilities of elected state members, 2014, 26.

110 Hand L, 'Is there a common will?' 28(1) Michigan Law Review, 1929, 52.

111 Para. 127 of Advisory opinion 2 of 2013. 
financial crisis. ${ }^{12}$ This would negate the constitutional mandate, which stipulates that the transfer of counties' share of revenue raised nationally must be done efficiently without undue delay. ${ }^{113}$ It is therefore also important that mediation is expedited and completed within the set budgeting timelines. The end of the law should always be the sovereign's best interest.

\section{ii. Exclusive legislation: Persuasive versus coercive power}

'Although the 2010 Constitution allows the National Assembly to originate Bills concerning counties and/or react to Bills concerning counties that originate from the Senate, the Senate has no power to react to many other legislative proposals originating from the National Assembly, unless such bills concern counties. It can therefore be said that the Senate's jurisdiction in so far as reacting to legislation originating from the National Assembly, is significantly constricted'. ${ }^{114}$

This type of authority vested in the senate that is significantly constricted can be termed persuasive power.

In the USA, the founding fathers conceptualised the senate as a second branch of the legislative assembly, which is distinct from and divides its power with the first (branch) and is in all cases a salutary check on the government. ${ }^{115}$ To secure this oversight function the senate has been given exclusive legislative command over treaty making together with the president ${ }^{116}$ and sole power to try all impeachments. ${ }^{117}$ While this may be a melange and ultimate confusion with the functionary objectives of the executive thus a pervasion of the doctrine of separation of powers, the essence can be deduced from the rationale for granting exclusive authority to one house in a bi-cameral government.

The senate should be given veto powers over the Division of Revenue Bill using a two-thirds majority vote to that effect (special veto powers), similar to the veto powers over the County Revenue Allocation Bill by the national assembly. Secondly, it should be charged with the power to enact the County Revenue

12 Para. 283 of Advisory opinion 2 of 2013.

113 Article 219, Constitution of Kenya (2010).

114 Kirui K and Murkomen K, The legislature: Bicameralism under the new constitution, 16.

115 Hamilton A and Madison J, The federalist, 403.

116 It could be argued however that this power of treaty making only extends to consent that is a yes or no over the negotiations between the president and foreign powers by a two-thirds majority vote of the senate therefore the upper house does not really give much perspective. See more, Bacon A, 'The treaty-making power of the president and the senate' 182 (593) The North American Review, 1906, 501-504.

117 Article 1(3), Constitution of the United States of America (1787). 
Allocation Bill solely. Two bodies can check this power. The first is the county assembly whose input will assist in ascertaining the needs of those the senate represents because, as mentioned before, they have closer linkages to the people whom they represent than the senate. The other is the CRA, which is already empowered by the current constitution to determine the horizontal and vertical allocation of revenue. In addition the senate draws a lion's share of representation in the CRA as compared to the national assembly thus more reason to give the upper house exclusive jurisdiction over horizontal allocation. ${ }^{118}$

\section{iii. Extended duration of electorate term}

'Politicians with longer terms are in a position to accumulate substantive expertise and human capital relevant to governing. Thus, it should come as no surprise that upper chambers frequently have responsibility to review and revise the work of the lower chambers. Indeed, in many upper chambers they may only review and revise matters related to the raising of revenue. In effect, the second chamber provides a second opinion... And, in those political systems where power has shifted dramatically to the lower chamber, the upper chamber is often restricted to a role of review and revision for all legislation. ${ }^{119}$

History suggests the existence of permanent senators for instance in Sparta, gerontes were elected by the Assembly of Spartans for life. ${ }^{120}$ Similarly, Rome had a senate for life because the selection of its members was based on status in terms of their experience and prestige in the community. ${ }^{121}$ Hamilton and Madison wrote that sufficient permanency was suitable for the required attention afforded to the legislative process. ${ }^{122}$ This notion is well worn as the members of the first senate of Kenya were elected for a period of six years. ${ }^{123}$ The tenure was:

'....intended to enable senators to achieve a degree of detachment from the more violent fluctuations of political mood and party politics... [emphasis mine]. The chances of fluctuation were further reduced by the provision that the expiration of the members' terms would be staggered so that no more than one-third of the seats would fall vacant at any one time' [emphasis mine]'. ${ }^{124}$

\footnotetext{
118 Article 215 (2) (b) and (c), Constitution of Kenya (2010). The two sections give two positions to the national assembly as compared to five positions from the senate.

119 Muthoo A and Shepsle K, 'The constitutional choice for bi-cameralism' Havard University Press, 11-12 $<$ http://scholar.harvard.edu/files/kshepsle/files/MuthooShepsleBICAMERALISM16thNov07-2. pdf? $\mathrm{m}=1360038865>$ on 18 November 2016.

120 Gerontes means senate body. See - <http://www.csun.edu/ hcfl004/sparta-c.html $>$ on 1 August 2016.

121 - <https://www.britannica.com/topic/Senate-Roman-history> on 1 August 2016.

122 Hamilton A and Madison J, The federalist, 409.

123 Constitution of Kenya Review Commission, Final draft, 2005, 183.

124 Proctor J, The role of the senate in the Kenyan political system, 394.
} 
It would be a point of reform if the members of the future senate could be sustained for one more year amid the on-going political changes (such as elections). ${ }^{125}$ In the USA, this has succeeded as they carry out regular elections every two years to ensure that no more than a third of the seats are vacant at any one time. $^{126}$

The apparent shortcomings of applying this recommendation in Kenya would be the costs incurred in carrying out these sorts of by-elections. Secondly, how would the senators pass laws in their extra year without the national assembly assuming the constitutional functions remain the same? This is the reason why the author argues in favour of granting exclusive legislative functions to the senate so that there is no interruption in governance. Even so, if they were to pass such laws exclusively would they be legitimate? It is therefore important to ensure that such powers carry democratic legitimacy as the stronger the legitimacy of a second chamber, the more likely it will be to make full use of its powers. ${ }^{127}$

\section{Recommendations and Conclusion}

The senate is critical for the counties' economies but lacks sufficient power to realise county fiscal capacity. Measures such as giving clarity to their mandate for the purpose of consistency in enacting legislation with the national assembly; conferring powers of exclusive jurisdiction over matters pertaining to allocation of revenue to the 47 counties together with the CRA or the county assemblies and extending the duration of tenure to six years so as to avoid political poisoning.

This paper sought to disprove the scrapping of the senate by illustrating its importance as the custodian of devolution in Kenya and more specifically the upholder for the advancing of county fiscal capacity. The first part tackled a summary on the tempestuous history of the senate, which was characterised by

125 In Kenya, the current trend is that a good number of senators prefer to run for governor in the oncoming election to the extent that there have been attempts to prevent them from pursuing such positions. See Ayaga W, 'Lock senators out of governor race, says team’ The Standard, 9 May 2016, <http://www.standardmedia.co.ke/article/2000201087/lock-senators-out-of-governor-race-saysteam/?pageNo $=2>$ on 18 November 2016.

126 This is known as a staggered term as compared to their equivalent to the national assembly which is known as the House of Representatives whose term is called a simultaneous term. It means that only a fraction of senators will be replaced at the end of each two-year congress. See Muthoo A and Shepsle K, 'The constitutional choice for bi-cameralism', 6-7.

127 International Institute for Democracy and Electoral Assistance, Bi-cameralism: (Legislatures with two chambers), August 2014, 6.- <http://www.constitutionnet.org/files/bicameralism_0.pdf $>$ on 18 November 2016. 
a series of deprivations of legislative authority. The crux of the paper followed this, which was an analytical discussion on how the senate performs its function of charting and steering the way for the allocation of revenue to the 47 counties to build their fiscal capacity. Lastly, this article concluded with instances of improvement borrowing from the relatively effective federal systems in the USA.

In the sentiments of retired Chief Justice Mutunga during his final address to the senate:

The place of the senate in the future of this country will only be secured when senate acts and behaves like the Upper House it was supposed to be; a house eminently capable of rising above narrow partisan politics; a house capable of engaging beyond the ethnic lens of the Kenyan politics; a house capable of debating real issues affecting Kenyans devoid of narrow political interests'.

The members of senate should not be arm-twisted to drop their bid of being custodians of devolution. 